\title{
Edukasi Budidaya Black Soldier Fly (BSF) dalam Rangka Menciptakan Lapangan Kerja Baru dan Solusi Permasalahan Sampah di Area Pasar Manis Ciamis
}

\author{
Hendar Nuryaman*1, Suprianto², Suyudi ${ }^{3}$, Nur Arifah Qurota A'yunin ${ }^{4}$ \\ 1,2,3 Program Studi Agribisnis, Fakultas Pertanian, Universitas Siliwangi \\ 4Program Studi Agroteknologi, Fakultas Pertanian, Universitas Siliwangi \\ *e-mail: hendarnuryaman@unsil.ac.id
}

\begin{abstract}
Waste becomes a problems if not managed properly, moreover comes from market activities whose are always there every day. Youth of Al Hilal live near "Pasar Manis" in Ciamis District, West Java, which some of the members do not have jobs. One of the activities in an effort to bring income is to cultivate the BSF (Black Soldier Fly), as a new breakthrough in providing cheap protein sources for animal feed and fish. This community service activity aims to provide education and management services for BSF cultivation in order to be able to utilize the economic potential of organic waste management and cultivation results. The method of activity is in the form of community education and BSF cultivation iptek with 34 participants. Generally, the results provide a new alternative to get income and improve skills in BSF cultivation so that is better in its management. Then an increase in understanding of the prospects, economic, social and environmental benefits so that it becomes an alternative solution in obtaining income and reducing the problem of organic waste in the surrounding area. The response of activities obtained by $88.2 \%$ greatly increases knowledge; $8.8 \%$ enough to add knowledge; and $2.9 \%$ are mediocre.
\end{abstract}

Keywords: Education, Hermetia illucens, Waste, Ciamis

\begin{abstract}
Abstrak
Sampah menjadi sumber masalah apabila tidak dikelola dengan baik, apalagi berasal dari aktifitas pasar yang kegiatannya selalu ada setiap hari. Pemuda karang taruna Al Hilal bertempat tinggal dekat "Pasar Manis" Kecamatan Ciamis, Jawa Barat yang sebagian anggotanya belum memiliki pekerjaan. Salah satu kegiatan dalam upaya untuk mendatangkan penghasilan adalah melakukan budidaya lalat BSF (Black Soldier Fly), sebagai terobosan baru dalam penyediaan sumber protein murah untuk pakan ternak dan ikan. Kegiatan pengabdian ini bertujuan memberikan jasa edukasi dan tata kelola budidaya BSF agar dapat memanfaatkan potensi ekonomi dari pengelolaan sampah organik dan hasil budidaya. Metode kegiatan berupa pendidikan masyarakat dan difusi iptek budidaya BSF dengan peserta 34 orang. Secara umum, hasil kegiatan ini memberikan alternatif baru guna mendapatkan penghasilan dan meningkatkan keterampilan dalam budidaya BSF sehingga lebih baik dalam pengelolaannya. Kemudian terjadi peningkatan pemahaman terhadap prospek, manfaat ekonomi, sosial dan lingkungan sehingga menjadi solusi alternatif dalam memperoleh penghasilan dan mereduksi masalah sampah organik diwilayah sekitar. Respon kegiatan diperoleh sebesar 88,2\% sangat menambah pengetahuan; 8,8\% cukup menambah pengetahuan; dan 2,9\% biasa saja.
\end{abstract}

Kata kunci: Edukasi, Hermetia illucens, Sampah, Ciamis.

\section{PENDAHULUAN}

Sampah merupakan masalah lingkungan yang sangat serius yang dihadapi masyarakat terutama bagi yang tinggal disekitar wilayah pasar. Ciamis merupakan salah satu kabupaten di Provinsi Jawa Barat yang memiliki produksi sampah cukup besar yaitu 560 ton/hari. Dalam pengelolaannya, hanya 20 persen yang mampu dikelola dan sisanya 80 persen dibuang ke TPA (Tempat Pembuangan Akhir). Sementara, daya tampung dan petugas sampah kurang memadai dan terbatas.

Di DKI Jakarta, dari total sampah yang dihasilkan setiap harinya, sebanyak 1.400 ton dihasilkan oleh seluruh pasar yang ada di Jakarta, dan 95\%-nya adalah sampah organik. Sampah organik seringkali menimbulkan bau dan penyakit. Belakangan ini, ditemukan kegiatan untuk mendaur ulang sampah organik dengan metode biokonversi. Umumnya, organisme yang 
berperan dalam proses biokonversi ini adalah bakteri, jamur, dan larva serangga (Suciati dan Faruq, 2017).

Biokonversi yang dilakukan oleh agen biokonversi yaitu larva BSF (Black Soldier Fly) atau yang biasa disebut juga maggot, ternyata mampu mengurangi limbah organik hingga $56 \%$ dan sebagai agen biokonversi, setidaknya ada tiga produk yang dapat diperoleh dengan memberdayakan larva BSF sebagai agen biokonversi (BB Veteriner, 2016). Serangga BSF memiliki beberapa karakter di antaranya dapat mereduksi sampah organik, dapat hidup dalam toleransi pH yang cukup tinggi, tidak membawa gen penyakit, mempunyai kandungan protein yang cukup tinggi (40-50\%), masa hidup sebagai larva cukup lama ( \pm 4 minggu) dan mudah dibudidayakan.

Penyediaan pakan ternak yang berkualitas merupakan salah satu faktor penentu keberhasilan industri peternakan dan menjadi komponen terbesar dalam kegiatan usaha tersebut, yaitu 50-70\% (Katayane et al. 2014). Di negara-negara berkembang, sumber protein untuk formula pakan umumnya bertumpu pada protein hewani dan nabati, seperti bungkil kedelai, tepung ikan, tepung darah atau tanaman leguminosa. Namun demikian, protein adalah komponen pakan paling mahal dibandingkan dengan yang lainnya. Akibatnya, secara ekonomi, pemenuhan sumber protein cukup membebani biaya produksi (Wardhana, 2016). Ketika ketersediaan bahan tersebut di dalam negeri minus, pemenuhan sumber protein pakan ternak dan ikan akan disuplai dari tepung ikan impor.

Menurut Wang dan Shilomi (2017), protein yang bersumber pada insekta lebih ekonomis, bersifat ramah lingkungan dan mempunyai peran yang penting secara alamiah. Insekta dilaporkan memiliki efisiensi konversi pakan yang tinggi dan dapat dipelihara serta diproduksi secara massal. Di samping itu, budidaya insekta dapat mengurangi limbah organik yang berpotensi mencemari lingkungan. Faktor lain yang menguntungkan adalah sumber protein berbasis insekta tidak berkompetisi dengan manusia sehingga sangat sesuai untuk digunakan sebagai bahan pakan ternak, termasuk unggas dan ikan (Veldkamp et al., 2015).

Budidaya BSF (Black Soldier Fly) merupakan suatu terobosan dalam penyediaan sumber protein murah untuk pakan ternak atau pakan ikan. Sudah banyak di beberapa negara maju, budidaya BSF dilakukan secara modern dan dalam skala industri besar. Di Indonesia, budidaya BSF sudah ada yang melakukannya dalam skala besar namun belum sampai pada teknologi yang telah dilakukan seperti di beberapa negara maju.

Banyak hasil kajian yang menunjukkan bahwa BSF yang merupakan larva Hermetia illucens (Linnaeus) (Diptera: Stratiomyidae) memiliki potensi sebagai pakan alternatif (Zakarni dan Miswarti, 2012). Secara ilmiah telah terbukti bahwa pemanfaatan tepung BSF pada babi, ayam petelur, ayam pedaging dan burung puyuh sebagai sumber alternatif protein dalam pakan ternak mempunyai prospek yang bagus terhadap pertumbuhan (Wardhana, 2016).

Larva BSF mampu mengkonversi limbah organik menjadi lemak dan protein dalam biomassa tubuhnya (Diener et al., 2011). Dengan memanfaatkan limbah organik melalui kegiatan budidaya lalat hitam BSF yang baik diharapkan akan mendorong terbentuknya unit usaha ternak dan usaha tani ikan yang berharga input murah (low cost input).

Mitra kegiatan ini adalah sekelompok pemuda yang tergabung dalam karang taruna $\mathrm{Al}$ Hilal yang berdomisili di wilayah Kecamatan Ciamis, khususnya yang bertempat tinggal dekat dengan "Pasar Manis", yaitu pasar yang bersebelahan dengan Rumah Sakit Umum Daerah (RSUD) dan Terminal Bus. Pada daerah tersebut, ditemukan masalah lingkungan yang cukup serius yaitu produksi sampah pasar yang melebihi kapasitas angkut untuk dimobilisasi ke TPS dan TPA, sehingga sisa sampah terakumulasi dan hal demikian dapat mencemari lingkungan sekitar.

Sebagian besar dari anggota karang taruna Al Hilal belum mempunyai pekerjaan atau penghasilan tetap dan mereka menginginkan kegiatan yang menghasilkan uang secara berkesinambungan. Salah satu upaya yang pernah mereka coba lakukan untuk mendapatkan kegiatan yang mendatangkan penghasilan adalah membudidayakan lalat BSF (Black Soldier Fly). Kegiatan yang dilakukan tidak berjalan dengan baik, karena cenderung melakukan kegiatan 
tersebut dengan hanya bermodalkan iseng "coba-coba". Hal tersebut diakibatkan kurangnya pengetahuan dan keterampilan yang dimiliki, sehingga hasilnya tidak sesuai dengan yang diharapkan. Sudah cukup lama keinginan para pemuda untuk belajar membudidayakan BSF, namun terkendala dengan keterbatasan akses dan biaya. Kalaupun ada yang bersedia memberikan kursus secara gratis, namun lokasinya jauh dari domisili mereka, sehingga pada akhirnya mereka tetap harus mengeluarkan biaya yang belum terjangkau.

Berdasarkan latar belakang tersebut, kegiatan pengabdian kepada masyarakat ini bermaksud memberikan jasa penyuluhan, pelatihan keterampilan budidaya BSF kepada masyarakat di sana khususnya para pemuda yang tergabung dalam karang taruna Al Hilal. Tujuan kegiatan ini adalah a) peningkatan pengetahuan dan keterampilan budidaya BSF bagi mitra, b) peningkatan respon pengetahuan dan keterampilan terhadap kegiatan penyuluhan budidaya BSF sehingga dapat menentukan langkah ke depan dalam melaksanakan budidaya BSF sebagai solusi mendapatkan penghasilan, serta produksi dan pengelolaannya meningkat, dan c) meningkatnya produksi dan produktivitas serta asset usaha yang dikelola mitra.

\section{METODE}

Waktu pelaksanaan kegiatan pengabdian ini dilakukan selama 8 bulan, mulai dari bulan Mei sampai dengan Desember 2019. Pelaksanaan kegiatan Pengabdian Kepada Masyarakat dengan skema Program Kemitraan Masyarakat (PKM) ini melibatkan berbagai pihak terkait diantaranya tim pelaksana sebanyak 3 orang, narasumber ahli terkait budidaya BSF sebanyak 2 orang, mahasiswa aktif yang tergabung di Himpunan Mahasiswa dan yang medapatkan beasiswa BI sebanyak 6 orang serta peserta sebanyak 34 orang yang berasal dari para pemuda yang tergabung dalam anggota karang taruna Al Hilal sebagai mitra yang berlokasi di Kelurahan Kertasari, Kecamatan Ciamis, Kabupaten Ciamis, Provinsi Jawa Barat.

Bahan dan alat yang digunakan yaitu sampah organik pasar, biopond yang terbuat dari kayu serta alat-alat lain yang digunakan untuk melakukan budidaya dan penangkapan lalat BSF dari alam seperti ember, dedak, air, bumbu penyedap dan minuman probiotik kemasan. Selain itu, kegiatan ini menggunakan lahan dan naungan sebagai tempat penyimpanan biopond untuk pembesaran larva lalat BSF menjadi maggot BSF sebagai tempat demplot.

Metode pelaksanaan kegiatan berupa kombinasi metode pendidikan masyarakat dan difusi iptek. Tahapan awal pelaksanaan meliputi persiapan kegiatan yaitu a) koordinasi dengan pihak-pihak yang terkait dengan kegiatan PPM ini, diantaranya adalah Dinas Lingkungan Hidup; Kepala Kelurahan, Kepala Lingkungan, RW dan RT setempat; b) survai ulang pemantapan gambaran kondisi eksisting; c) sosialisasi detail rencana kegiatan terhadap anggota karang taruna yang ikut serta sebagai mitra; d) pelatihan, penyuluhan dan difusi iptek budidaya BSF melalui "demplot" yang diawali dengan diskusi, ceramah dan praktek (learning by doing), serta diakiri dengan evaluasi kegiatan.

Hasil tahap awal kegiatan yang berupa survei lokasi eksisting kepada karang taruna pemuda Al Hilal di Kelurahan Kertasari, Kecamatan Ciamis, Kabupaten Ciamis, Provinsi Jawa Barat serta melihat potensi sumber daya penunjang kegiatan budidaya BSF menunjukkan bahwa kondisi pengelolaan sampah organik dari limbah pasar pada umumnya belum dilakukan secara optimal. Para pemuda tidak melihat bahwa dari sampah tersebut tersimpan potensi ekonomi yang besar apabila dikelola dengan baik serta dapat memberikan dampak positif terhadap lingkungan sekitar karena bisa mereduksi volume sampah organik yang dapat berkontribusi terhadap penyelesaian permasalahan sampah. (Gambar 1) menunjukkan kondisi tidak terkelolanya sampah Pasar Manis, yaitu pasar yang bersebelahan dengan Rumah Sakit Umum Daerah dan Terminal Bus yang terletak di sekitar mitra kegiatan pengabdian masyarakat ini. Permasalahan yang terungkap dalam tergambarkan secara implisit sebagai berikut:

- Terdapat produksi sampah pasar yang melebihi kapasitas angkut untuk dimobilisasi ke TPS dan TPA, sehingga kondisinya terakumulasi dan mencemarkan lingkungan sekitar;

- Lebih dari 50 persen anggota karang taruna Al Hilal belum punya pekerjaan/penghasilan tetap, 
dan ingin memiliki kegiatan/perkerjaan yang menghasilkan uang secara berkesinambungan;

- Adanya keinginan dari anggota karang taruna yang berdomisili sekitar pasar tersebut dalam memanfaatkan sampah organik untuk budidaya BSF, namun pengetahuan dan keterampilan belum cukup mereka miliki.

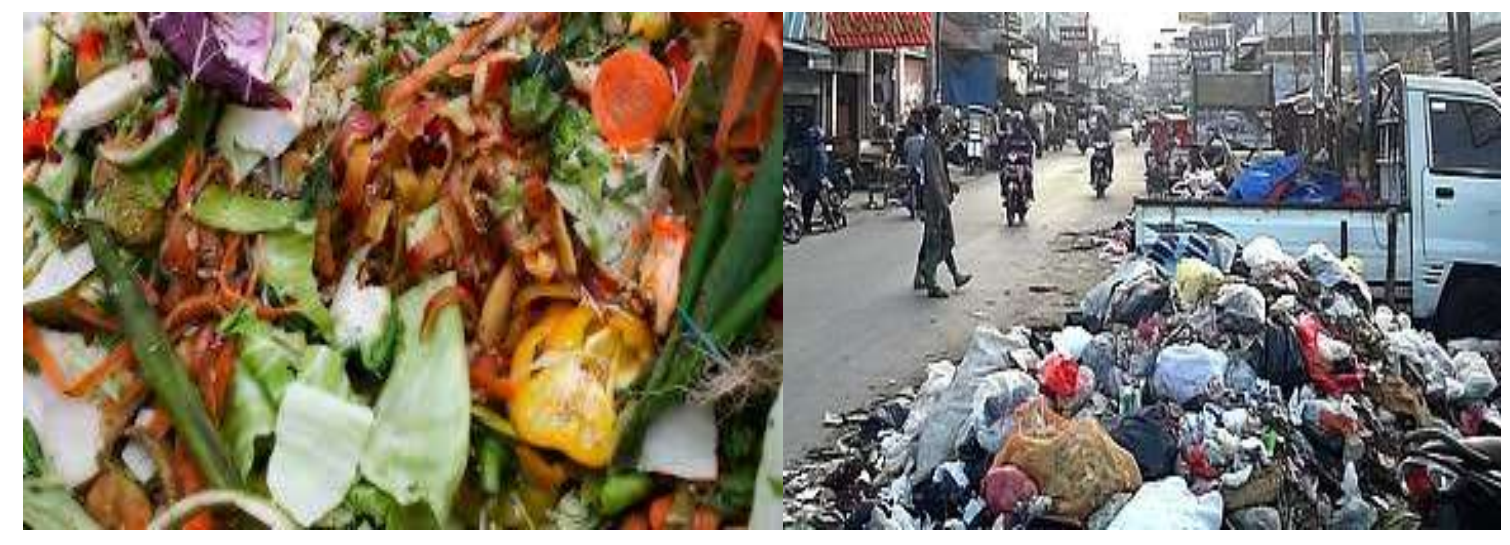

Gambar 1. Kondisi sampah organik pasar yang tidak terkelola dengan baik

Kegiatan PPM-PKM ini secara resmi baru dimulai pada tanggal 14 Juli 2019 oleh perwakilan dari LP2MP-PMP Universitas Siliwangi, yang dihadiri oleh Ketua Pemuda Al Hilal, anggota DPRD kabupaten Ciamis, tokoh masyarakat serta tim pelaksana. Setelah dilakukan pembukaan secara resmi, kemudian dilanjutkan dengan kegiatan inti pengabdian masyarakat oleh tim pelaksana dan narasumber serta mahasiswa yang ikut serta membantu. Rincian materi kegiatan PPM seperti pada Tabel 1.

Tabel 1. Tujuan, Metode, Bentuk Kegiatan dan Pelaksana Pengabdian

\begin{tabular}{lll}
\multicolumn{1}{c}{ Tujuan } & Metode/Bentuk Kegiatan & \multicolumn{1}{c}{ Pelaksana } \\
\hline $\begin{array}{l}\text { a. Penyamaan persepsi dan motivasi } \\
\text { b. Brainstorming prospek manfaat } \\
\text { sosial, ekonomis dan ekologis } \\
\text { budidaya BSF }\end{array}$ & $\begin{array}{l}\text { FGD/Diskusi Terfokus } \\
\text { Ceramah, Diskusi, }\end{array}$ & $\begin{array}{l}\text { Hendar Nuryaman, } \\
\text { Nur Arifah Q. A, } \\
\text { Pemutaran Film }\end{array}$ \\
$\begin{array}{ll}\text { c. Penyuluhan prospek pasar maggot } \\
\text { BSF }\end{array}$ & $\begin{array}{l}\text { Ceramah, Diskusi, } \\
\text { Pemutaran Film }\end{array}$ & Suyudi \\
$\begin{array}{l}\text { d. Penyuluhan tata kelola, budidaya } \\
\text { BSF untuk menghasikan maggot }\end{array}$ & $\begin{array}{l}\text { Ceramah, Diskusi, Learning } \\
\text { by doing }\end{array}$ & $\begin{array}{l}\text { Hendar Nuryaman, } \\
\text { Suprianto, }\end{array}$ \\
$\begin{array}{l}\text { e. Penyuluhan tata kelola, maggot BSF } \\
\text { yang dijadikan induk }\end{array}$ & $\begin{array}{l}\text { Ceramah, Diskusi, Learning } \\
\text { by doing }\end{array}$ & Nur Arifah Q. A \\
$\begin{array}{l}\text { f. Penyuluhan tata kelola, maggot } \\
\text { yang akan digunakan pakan } \\
\text { ternak/ikan }\end{array}$ & $\begin{array}{l}\text { Ceramah, Diskusi, Learning } \\
\text { by doing }\end{array}$ & $\begin{array}{l}\text { Suyudi, } \\
\text { Suprianto }\end{array}$ \\
$\begin{array}{l}\text { gevitalisasi kepengurusan Karang } \\
\text { taruna Al Hilal }\end{array}$ & Diskusi, Mediasi & Hendar Nuryaman \\
\hline
\end{tabular}

Penyampaian materi penyuluhan disertai dengan diskusi dua arah antara peserta dengan pemateri sebagai narasumber yang bertujuan untuk menggali informasi lebih jauh mengenai kesungguhan dalam mengikuti kegiatan ini. Kemudian memberikan pemahamanpemahaman lebih dalam terkait manfaat dari kegiatan usaha budidaya BSF apabila dilaksanakan dan dikelola dengan baik yang berorientasi pasar untuk diperjualbelikan sebagai solusi atas permasalahan sampah organik pasar serta menciptakan lapangan kerja baru bagi para pemuda karang taruna Al Hilal (Gambar 2). 


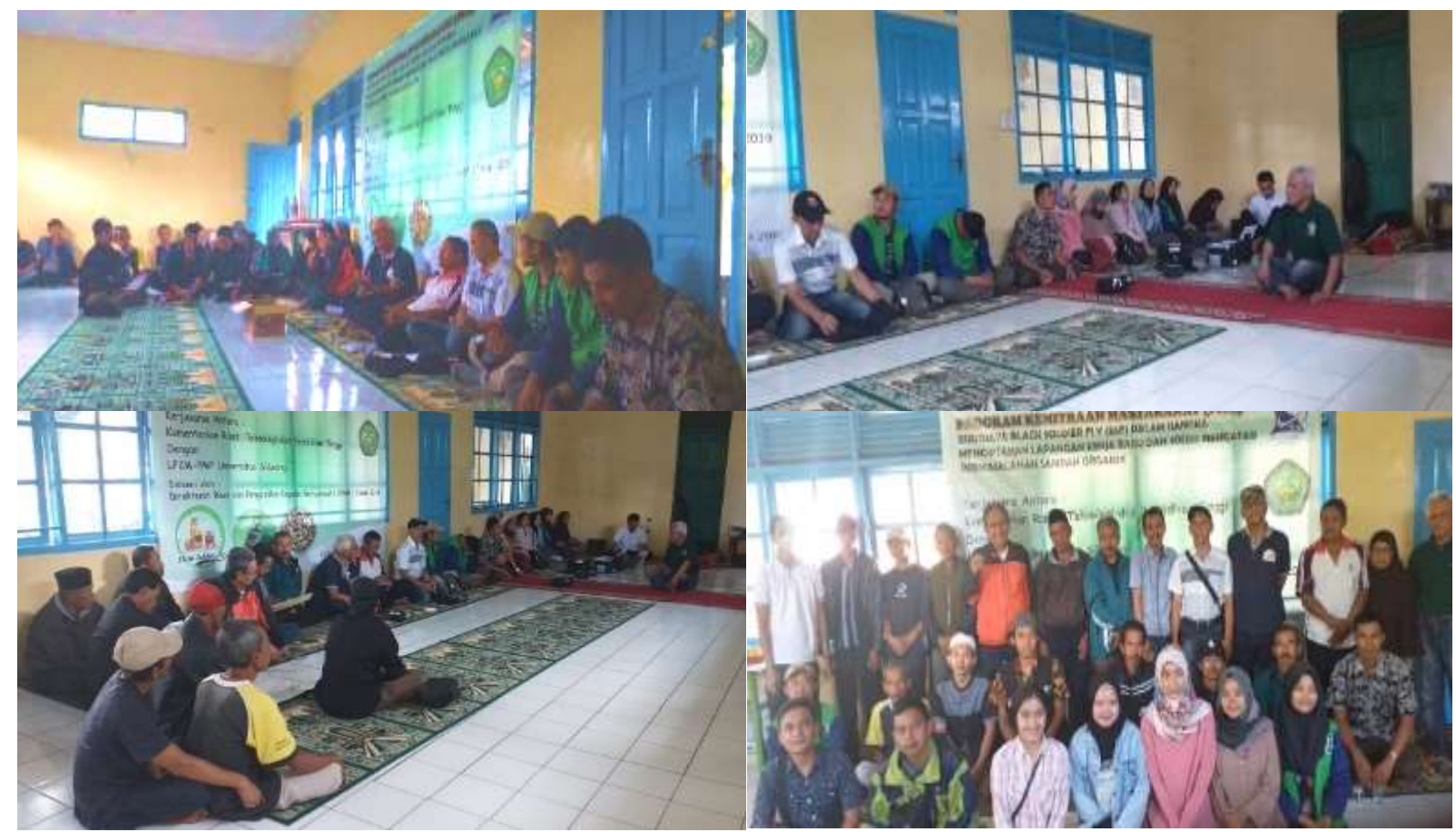

Gambar 2. Rangkaian Kegiatan Brainstorming, Diskusi, dan Penyuluhan Budidaya BSF

Hasil pada tahap difusi iptek dari kegiatan ini berupa demplot pembuatan bangunan naungan (Gambar 3), pembuatan kandang dan biopond (Gambar 4), dan praktik tata kelola serta cara menangkap lalat BSF dari alam (Gambar 5). Pembuatan bangunan naungan untuk budidaya lalat BSF dimaksudkan agar pada proses kegiatan budidaya BSF dapat terlindungi dari panas matahari dan hujan secara langsung, bangunan naungan terbuat dari bahan baja ringan agar bisa kuat dan fleksibel ketika terjadi gempa, kemudian bangunan naungan dibiarkan terbuka disetiap pinggirnya supaya oksigen tersirkulasi dengan baik, karena lalat BSF akan tumbuh dengan baik seolah-olah seperti berada di alam terbuka.

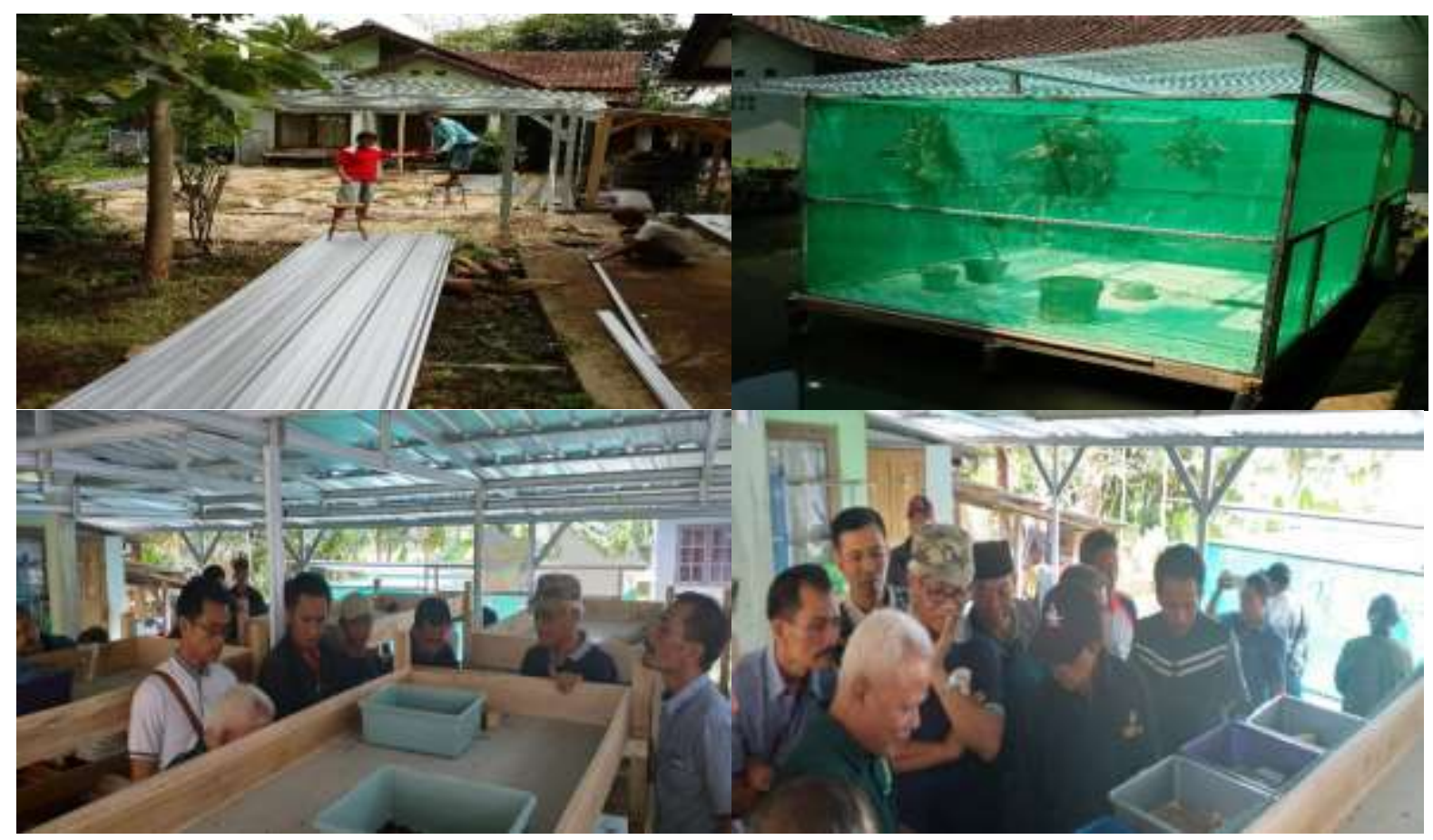

Gambar 3. Pembuatan naungan, kandang untuk menghasilkan telur, biopond untuk pembesaran larva BSF, dan praktek tata kelola serta menangkap lalat BSF dari alam. 


\section{HASIL DAN PEMBAHASAN}

Hasil dan pembahasan dari pelaksanaan kegiatan Pengabdian Kepada Masyarakat dengan skema Program Kemitraan Masyarakat yang telah dilakukan dapat dijelaskan sebagai berikut :

\subsection{Perubahan Pengetahuan dan Pemahaman Mitra}

Rincian materi yang disampaikan pada kegiatan pengabdian ini meliputi 6 materi inti yaitu materi umum, sosek dan lingkungan, pemasaran, teknis budidaya, panen dan pasca panen serta materi terkait dengan kelembagaan. Materi-materi inti tersebut kemudian disusun menjadi sebanyak 7 butir soal quiz dengan dibuatkan pula kode untuk masing-masing materi (Tabel 2).

Tabel 2. Sub Materi, Jenis Materi dan Kode Quiz dalam Pelaksanaan Kegiatan Pengabdian

\begin{tabular}{cllc}
\hline No & \multicolumn{1}{c}{ Sub Materi } & \multicolumn{1}{c}{ Jenis Materi } & Kode Quiz \\
\hline 1 & $\begin{array}{l}\text { Pengetahuan dan Pemahaman tentang Budidaya } \\
\text { Lalat BSF }\end{array}$ & Umum \\
2 & $\begin{array}{l}\text { Pengetahuan dan Pemahaman tentang manfaat } \\
\text { sosial, ekonomis dan ekologis budidaya BSF }\end{array}$ & Sosek dan Lingkungan & B \\
3 & $\begin{array}{l}\text { Pengetahuan dan Pemahaman prospek pasar } \\
\text { maggot BSF }\end{array}$ & Pemasaran \\
4 & $\begin{array}{l}\text { Pengetahuan dan Pemahaman tentang tata } \\
\text { kelola, budidaya BSF untuk menghasikan } \\
\text { maggot }\end{array}$ & D1 \\
5 & $\begin{array}{l}\text { Pengetahuan dan Pemahaman tentang tata } \\
\text { kelola, maggot BSF yang dijadikan induk }\end{array}$ & Teknis Budidaya \\
$\begin{array}{l}\text { Pengetahuan dan Pemahaman tentang tata } \\
\text { kelola maggot yang akan dijadikan pakan } \\
\text { ternak/ikan }\end{array}$ & $\begin{array}{l}\text { Panen dan Pasca } \\
\text { Pengetahuan dan Pemahaman tentang } \\
\text { berorganisasi }\end{array}$ & E & E \\
\hline
\end{tabular}

Hasil monitoring dan evaluasi dengan cara membandingkan hasil quiz yang diberikan antara sebelum dan sesudah kegiatan dilaksanakan menunjukkan bahwa terdapat perubahan tingkat pemahaman mitra/peserta terhadap kegiatan budidaya BSF yang dialaksanakan dengan rata-rata perubahan sebesar 42 persen (Gambar 4).

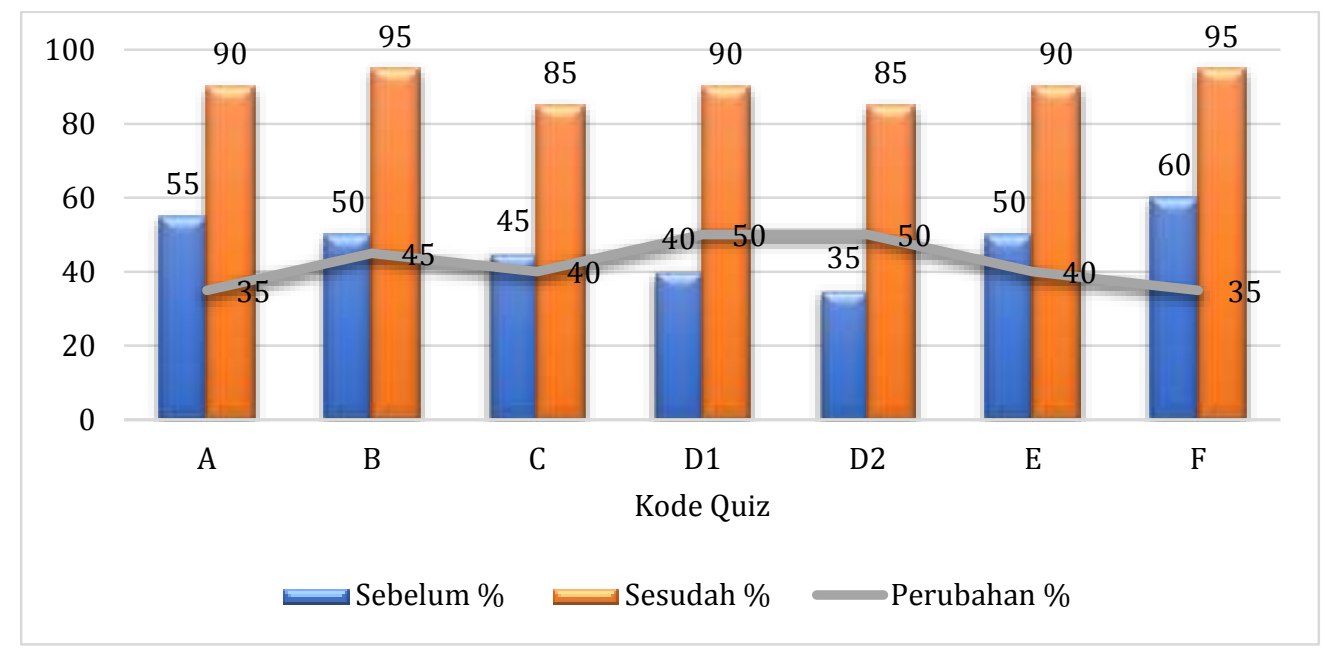

Gambar 4. Persentase Perubahan Tingkat Pemahaman Mitra Terhadap Budidaya BSF Antara Sebelum dan Sesudah Adanya Kegiatan Pengabdian 


\subsection{Respon Mitra Terhadap Kegiatan yang Dilaksanakan}

Selama kegiatan pengabdian ini berlangsung, antusiasme mitra untuk mengikuti kegiatan sangat besar, sebagaimana telah diketahui bahwa berdasarkan serangkaian kegiatan pengabdian masyarakat yang sudah dilakukan, diperoleh hasil bahwa terjadi peningkatan pengetahuan dan keterampilan mitra dalam hal ini pemuda yang tergabung dalam kelompok karang taruna Al Hilal dalam melakukan budidaya BSF. Selain itu, para pemuda juga tidak lagi melakukan kegiatan budidaya BSF dalam kandang yang kecil, namun sudah mampu mengelola BSF dalam kandang besar.

Berdasarkan (Gambar 5) diketahui bahwa respon mitra terhadap kegiatan yang sudah dilaksanakan sebesar 88,2 persen anggota mitra kegiatan menyatakan sangat menambah pengetahuan dari sebelumnya sebesar 32,4 persen; sebesar 8,8 persen menyatakan cukup menambah pengetahuan dari sebelumnya sebesar 52,9 persen; dan sebesar 2,9 persen menyatakan biasa saja dari ssebelumnyaebesar 14,7 persen. Hal ini sejalan dengan hasil pengabdian (Yermadona et al., 2019) yang menyatakan bahwa hasil pengukuran kuisioner akhir (post-test), tingkat pemahaman peserta terhadap produksi VCO oleh Ibu-Ibu PKK Nagari Sikucur Barat yang diberikan setelah dilakukan sosialisai beberapa kali. Peserta dapat menjawab hampir seluruh pertanyaan, pengetahuan peserta meningkat menjadi sebesar 89,4 persen dari sebelumnya sebesar 42,8 persen.

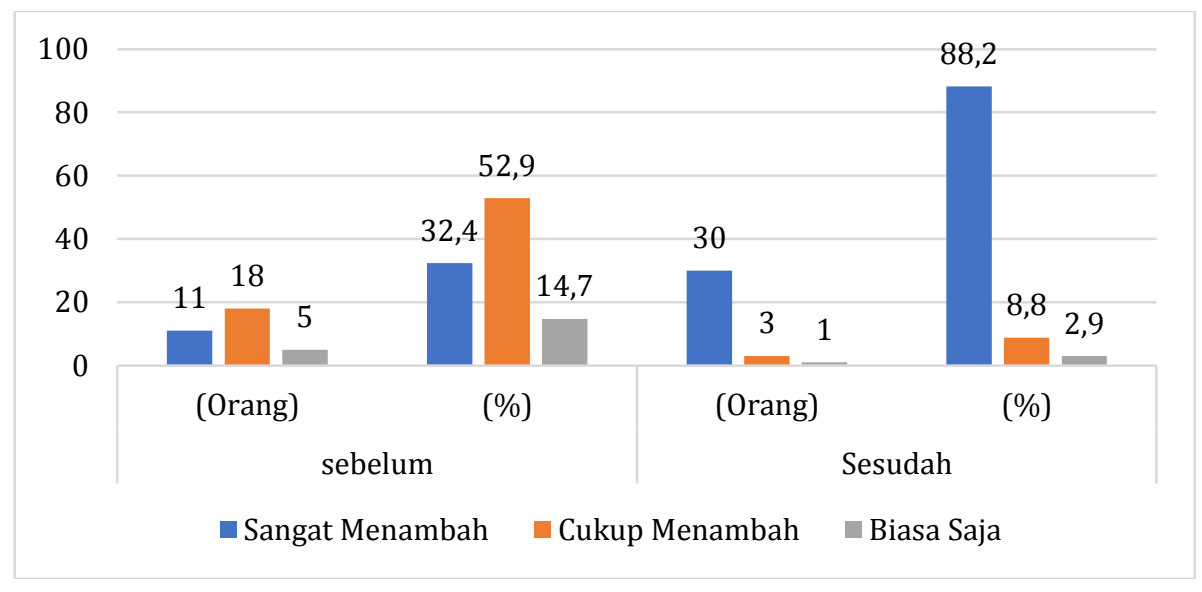

Gambar 5. Respon mitra sebelum dan sesudah kegiatan pengabdian dilaksanakan

\subsection{Peningkatan Produksi, Produktivitas dan Asset yang Dikelola}

Hasil dari kegiatan ini berdampak positif karena produksi, produktivitas, dan pendapatan, serta asset usaha yang dikelola oleh mitra pengabdian menjadi meningkat. Sampai dengan akhir pelaksanaan kegiatan ini, diketahui bahwa telah terjadi perubahan terhadap peningkatan kapasitas produksi antara sebelum mendapatkan penyuluhan, pelatihan dan difusi iptek budidaya BSF serta sekaligus dilakukan pendampingan dari tim pelaksana pengabdian, diantaranya yaitu:

- Sebelum kegiatan pengabdian dilaksanakan, hasil larva maggot BSF yang diperoleh serta siap untuk sebagai pakan ternak/ikan sebanyak 30-60 kg per periode produksi (21 hari).

- Setelah kegiatan pengabdian dilaksanakan, hasil larva maggot BSF yang diperoleh serta siap untuk sebagai pakan ternak/ikan menjadi sebanyak 250-350 kg per periode produksi (21 hari).

Produk maggot BSF yang dihasilkan dari kegiatan pengabdian ini selanjutnya digunakan atau diaplikasikan sebagai pakan ikan dikolam yang dimiliki oleh kelompok pemuda Al Hilal (Gambar 6). 


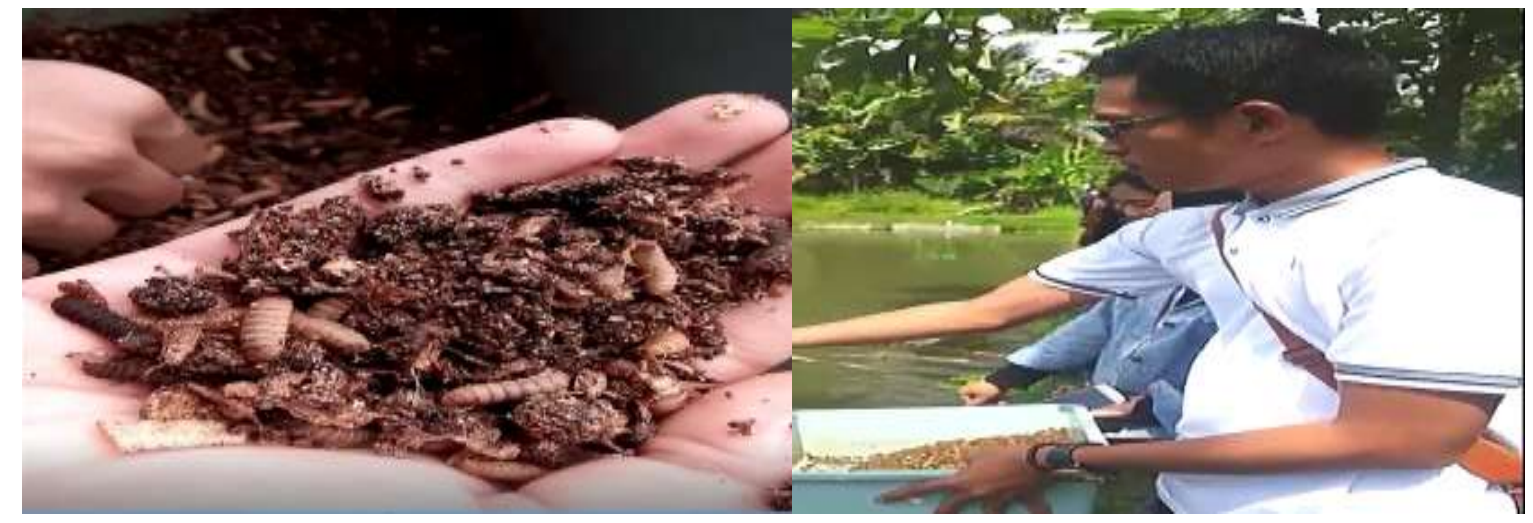

Gambar 6. Produk maggot BSF yang dihasilkan dan diaplikasikan untuk pakan ikan

\section{KESIMPULAN}

Berdasarkan hasil-hasil yang diperoleh selama kegiatan PKM, kelebihan dan kekurangannya, serta kemungkinan pengembangan selanjutnya, dapat disimpulkan sebagai berikut:

1. Setelah mengikuti kegiatan pengabdian ini, para pemuda mengetahui prospek, manfaat ekonomi, sosial dan lingkungan budidaya BSF sehingga menjadi alternatif solusi dalam mendapatkan penghasilan dan mereduksi masalah sampah organik di wilayah sekitar.

2. Terdapat perubahan tingkat pemahaman mitra/peserta terhadap kegiatan budidaya BSF yang dialaksanakan dengan rata-rata perubahan sebesar 42 persen.

3. Kegiatan penyuluhan, pelatihan dan adanya praktek melalui demplot mendapatkan respon dari para pemuda sebesar 88,2 persen sangat menambah pengetahuan dari sebelumnya sebesar 32,4 persen; 8,8 persen cukup menambah pengetahuan dari sebelumnya sebesar 52,9 persen dan 2,9 persen biasa saja dari sebelumnya sebelumnya 14,7 persen.

4. Kegiatan ini berdampak positif karena produksi, produktivitas, dan pendapatan, serta asset usaha yang dikelola oleh mitra pengabdian menjadi meningkat dan memberikan alternatif baru bagi para pemuda guna mendapatkan penghasilan dan keterampilan dalam budidaya BSF sehingga lebih baik lagi dalam pengelolaannya.

5. Hasil kegiatan pengabdian pada masyarakat ini masih perlu dikembangkan bagi masyarakat luas, khususnya para pemuda sebagai mitra dan tim pengabdian sebagai narasumber agar kerjasama ini terus berlanjut untuk menyempurnakan program-program lainnya yang belum tercapai seperti pengolahan maggot BSF menjadi pakan berbentuk pelet

\section{UCAPAN TERIMA KASIH}

Penulis mengucapkan terima kasih kepada semua pihak yang telah berpartisipasi sehingga kegiatan Pengabdian Kepada Masyarakat, Kompetitif Nasional dengan Skema Program Kemitraan Masyarakat (PKM) ini dapat berjalan lancar, baik melalui komunikasi lisan maupun tulisan, terutama kepada:

1. Kemenristekdikti melalui DRPM yang telah membiayai kegiatan pengabdian ini dengan Pembiayaan tahun 2019 Sesuai dengan Perjanjian Penugasan Pelaksanaan Program Pengabdian Masyarakat Nomor: 092/SP2H/PPM/DRPM/2019, tanggal 18 Maret 2019.

2. LP2M-PMP Universitas Siliwangi.

3. Anggota DPRD Kabupaten Ciamis yang ikut serta dalam kegiatan pengabdian ini.

4. Dinas Lingkungan Hidup, Kepala Kelurahan, Kepala Lingkungan, RW dan RT setempat.

5. Pemuda Karang Taruna Al Hilal Ciamis sebagai Mitra Pengabdian.

6. Himpunan Mahasiswa dan yang medapatkan beasiswa BI (GenBI). 


\section{DAFTAR PUSTAKA}

Balitbangtan (BB Veteriner). Maret 2016. Lalat Tentara Hitam Agen Biokonversi Sampah Organik Berprotein Tinggi. Diakses dari: http://www.litbang.pertanian.go.id/berita/on e/2557/ (diakses 10 Juni 2019)

Diener S, Solano NM, Gutierrez FR, Zurbrugg CT. 2011. Biological treatment of municipal organic waste using black soldier fly larvae. Waste Biomass Valor 2(1): 357-63.

Katayane, Falicia A.; B. Bagau; F. R. Wolayan \& M. R. Imbar. Mei 2014. Produksi dan Kan- dungan Protein Maggot (Hermetia illucens) Dengan Menggunakan Media Tumbuh Ber- beda. Jurnal zootek ("zootek journal") vol 34 (edisi khusus):27 - 36 (Mei 2014) ISSN 0852-2626

Suciati, R., dan Faruq, H. 2017. Efektifitas Media Pertumbuhan Maggots Hermetia Illucens (Lalat Tentara Hitam) Sebagai Solusi Pemanfaatan Sampah Organik. Biosfer: Jurnal Biologi dan Pendidikan Biologi, 2(1), 0-5. https://doi.org/10.23969/biosfer.v2i1.356

Veldkamp T, Bosch G. 2015. Insects: A protein-rich feed ingredient in pig and poultry diets. Anim Front. 5:45-50.

Wardhana, A. H. 2016. Black soldier fly (Hermetia illucens) sebagai sumber protein alternatif untuk pakan ternak. Wartazoa: Buletin Ilmu Peternakan Dan Kesehatan Hewan Indonesia, 26(2), 69-78. https://doi.org/10.14334/wartazoa.v26i2.1327

Wang YS, Shelomi M. 2017. Review of black soldier fly (Hermetia illucens) as animal feed and human food. Foods 6 (21): 1-23.

Yermadona, H., Earnestly, F., Afrijon, Suryani, \& Firdaus. 2019. Pemberdayaan Ibu-ibu PKK Nagari Sikucur Barat Melalui Produksi Virgin Coconut Oil (VCO). Dinamisia: Jurnal Pengabdian Kepada Masyarakat, 3, 171-180. https://doi.org/10.31849/dinamisia.v3i0.2918

Zakarni, A., dan Miswarti, M. 2012. Teknik budi daya larva Hermetia illucens (Linnaeus) (Diptera: Stratiomyidae) sebagai sumber protein pakan ternak melalui biokonversi limbah loading ramp dari pabrik CPO. Jurnal Entomologi Indonesia, 9(2), 49-56. https://doi.org/10.5994/jei.9.2.49 